
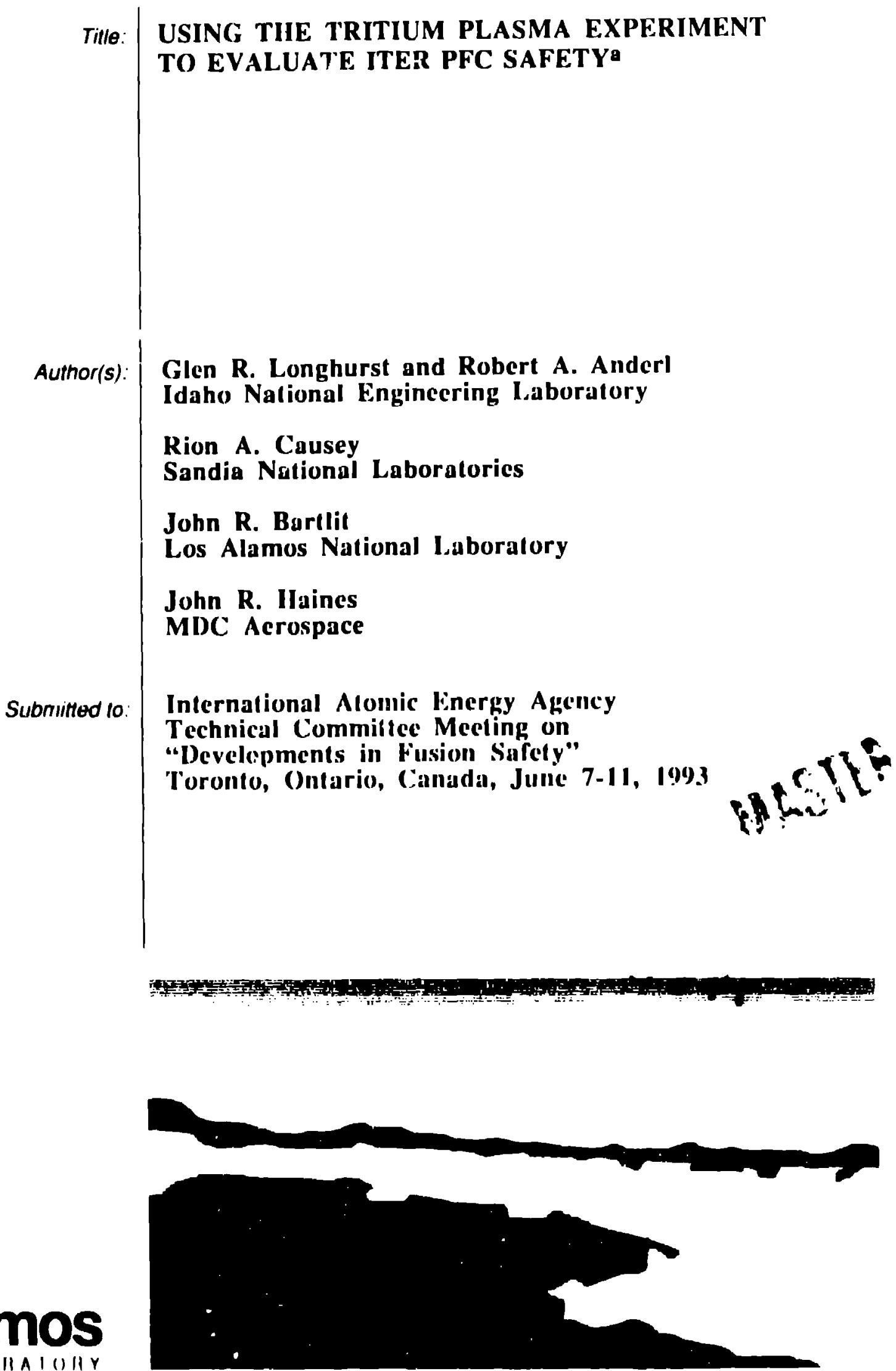

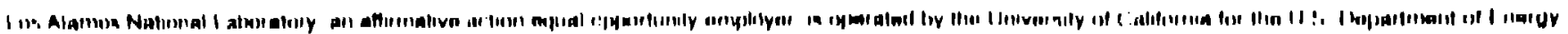

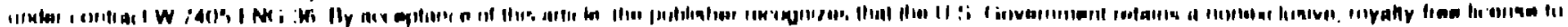

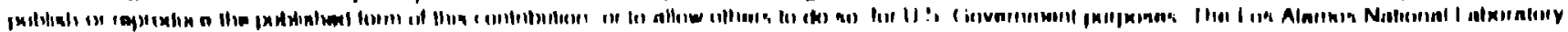

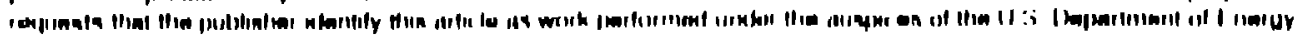




\title{
Using the Tritium Plasma Experiment to Evaluate ITER PFC Safety
}

\author{
Glen R. Longhurst and Robert A. Anderl \\ Idaho National Engineering Laboratory \\ Idaho Falls, ID 83415-3880 \\ Rion A. Causey \\ Sandia National Laboratories \\ Livermore, CA 94551-0969
}

\author{
John R. Bartlit \\ Los Alamos National Laboratory \\ I,os Alamos, NM 87545 \\ Jolnn R. Haines \\ MDC Acrospace \\ St. L.ouis, MO 63166
}

\begin{abstract}
The Tritium Plasma Experiment was assembled at Sandia National Laboratories, Livermore to investigate interactions between dense plasmas at low energies and plasma-facing component materials. This apparatles has the unique capability of replicating plasma conditions in a tokamak divertor with particle flux densities of $2 \times 10^{19}$ ions $/ \mathrm{cm}^{2} \cdot \mathrm{s}$ and al plasmat temperature of about $15 \mathrm{eV}$ using a plasma that includes tritium. With the closure of the Tritium Research Laboratory at Livermorc, the experiment was moved to the Tritium Systems Test Assembly facility at los Alamos National I.aboratory. An experimental program has been initiated there using the Tritium Plasima lixperiment to eximine safety issues relined to tritium in plasmit-facing components, particularly the ITlER divertor. Those issues include tritiun retention and release characteristics, tritimn permeation rates and transient time:s to coolant streans, surface modilication and crosion by the plasina, the cflects of thermall loikds and cycling, ind particulate: production. A considerable lack of daltit exist: in these anceis for many of the materials, especially beryllium, being considered for use in Illik. Not only will basic: material behavior with respect to sialecty issuess in the

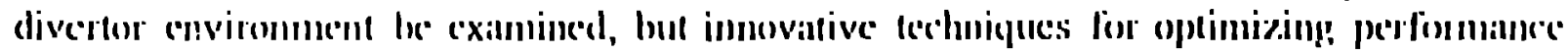

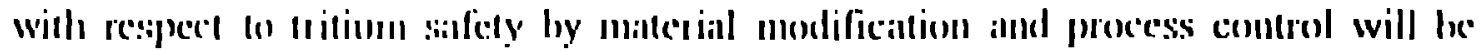

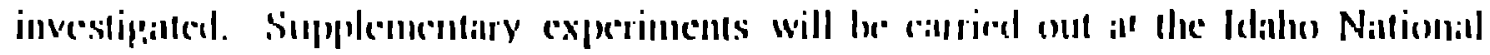

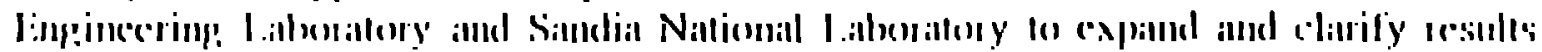

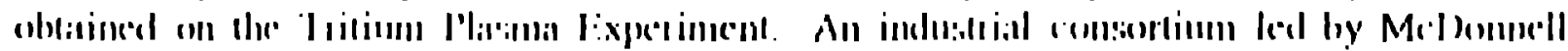

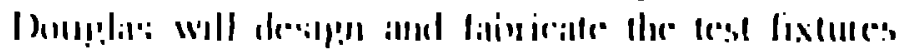

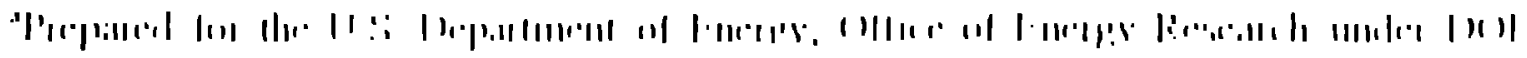

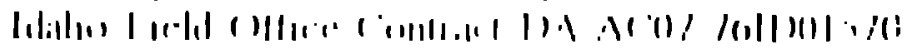




\section{INTRODUCTION}

Safety is one of many issues facing the designers of plasma-facing components (PFCs) of the International Thermonuclear Experimental Reactor (ITER) and other developmental fusion machines. In many areas, the sarety of systems and components may be reasonably well estimated from existing test data or using existing analytical tools. For PFCs, however, there are safety concerns for which there are few if any prior results on which to base design decisions.

The ability to simulate the environment encountered by PICs is a key one in developing the experimental data base for PFC safety. That capability exists in the Tritium Plasmi Experiment (TPE) , an apparatus initially constructed at Sandia National Laboratories, Livermore (SNLL), and now planned for operation at the Tritium Systems Test Assembly (TSTA' at I.os Alamos National Laboratory (LANL). The experimental apparatus has a nominal particle flux of $2 \times 10^{24} \mathrm{iras} / \mathrm{m}^{2} . \mathrm{s}$, a tackground gas pressure of $13 \mathrm{mPa}$, a plasnia densily of $2 \times 10^{19} \mathrm{ion} / \mathrm{m}^{3}$, an electron lempurature of $15 \mathrm{eV}$, and a magnetic field intensity of 0.25 tesla. The volume available for the test article is nominally two liters. The configuration of the device is essentially the same as that of the PISCI:S-A facility at UC:I.A. ${ }^{(1)}$

A project involving the collalxorative efforts of the Idaho National linginecring 1.nboratory (INI:I.), SNI.I., TSTA, and an industrial consortiun led by MI)C Aerospace hats been initiated to investignte stifety issues for PliCs using the TIPl: facility. The purpuse of this reprott is to lay the hackground for undertaking that task, to outline technical and

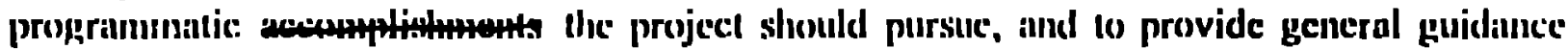
(o) experiment slesigners. Jyen/s

The INI:I, hess varied interests in this experimental prop!lim! 'The lousion Safrty

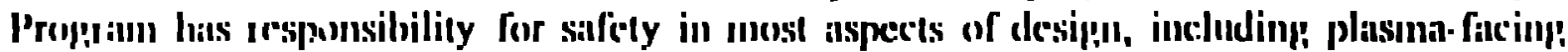

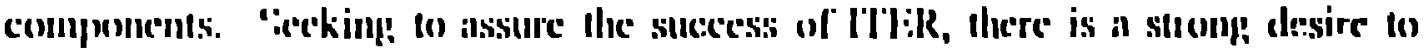

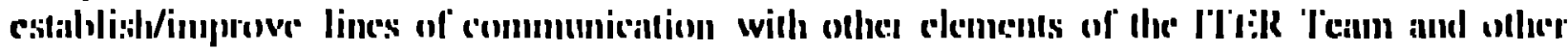

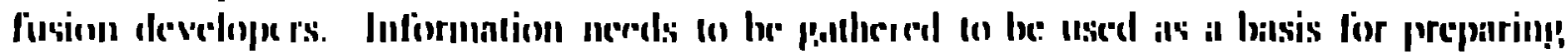

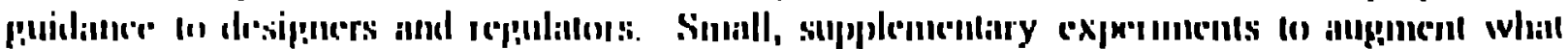

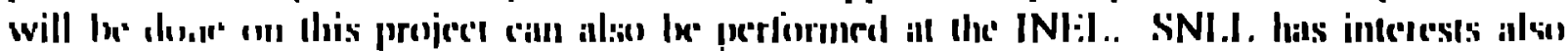

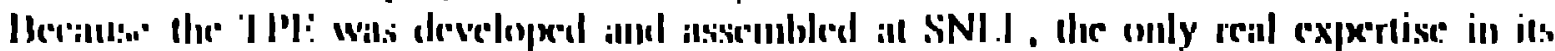

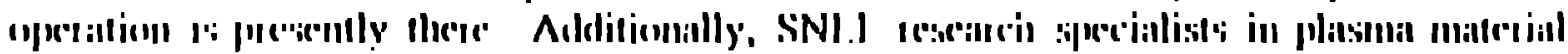

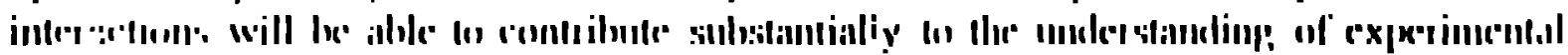

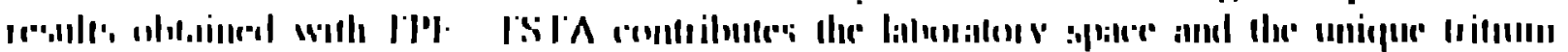

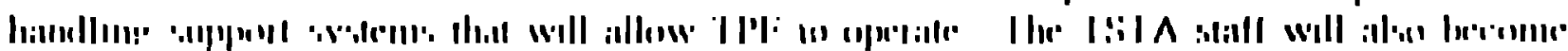
; |

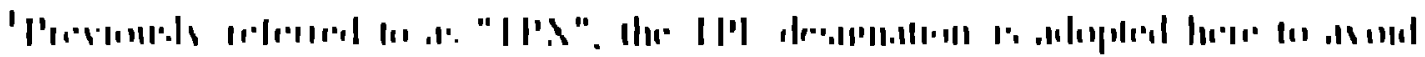

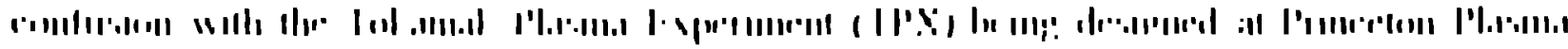

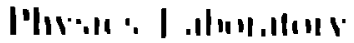


of PFCs. In that role, they will be designing and developing many of the internal components for the U.S. ITER Home Team. This combination of resources should assure success of the project.

\section{SAFETY CONSIDERATIONS}

In this section, the background is laid for investigation of the various safety issues associated with PFCs. Safety is a major consideration in the ultimate viability of fusion power as an energy source. In a typical commercial fission reactor power plant in the U.S. almost half of the total operating costs are not associated with plant maintenance or fuel. but with operating procedures that are strongly driven by the costs of securing and maintaining public acceptance through documentation of safety-related performance. Approximately 20,000 pages of licensing correspondence must be prepared each year tor a representative pressurized water reactor. Unless fusion can be shown to have substantially grenter inherent safety characteristics that fission renetor sy'stems, we may expect that the costs of documenting compliance with the various environmental and safety regulations will he as high for fusion as they are for fission. Since initial capital costs will be higher for fusion, there will be no incentive for commercialization. Thus, safely in fusion is one of the hight-priority conceans in fusion development. Safety of plasma-facing components is a signtificint patrt of that concern.

\section{Tritium Inventory and Accountability}

(11-silt: tritium is a major factor in the radiological hazard assseciated with any' tritum.hurniny! fusion reactur. W/hile systems stoch iss the fucl stura!ge and injection

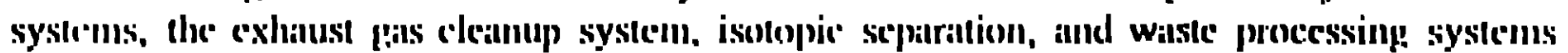

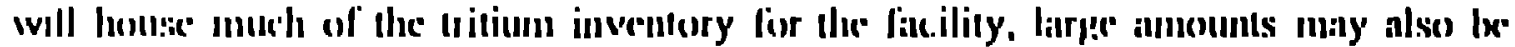

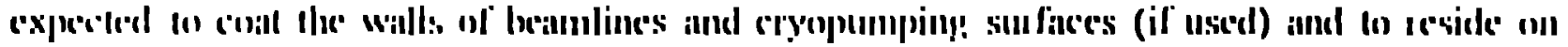

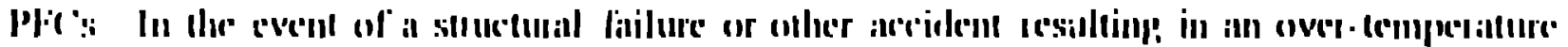

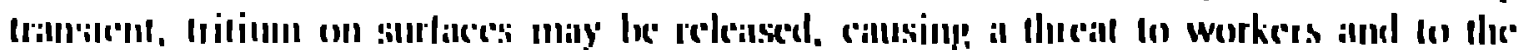

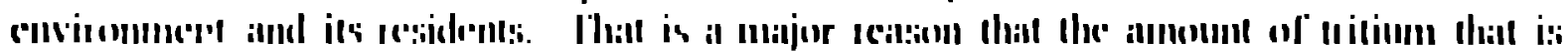

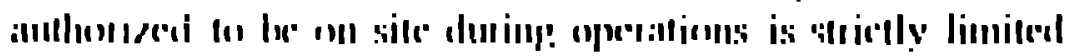

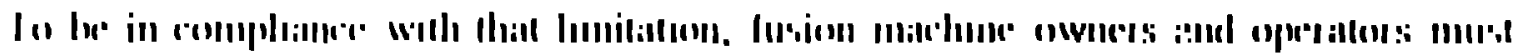

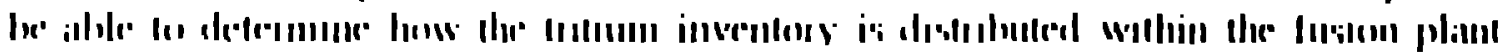

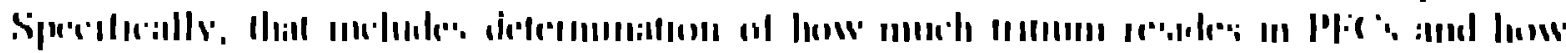

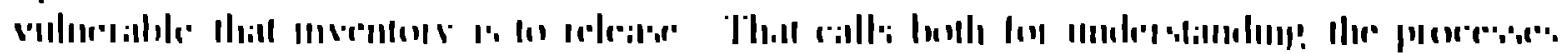

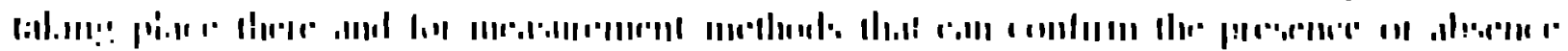

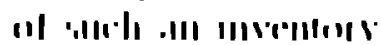

每

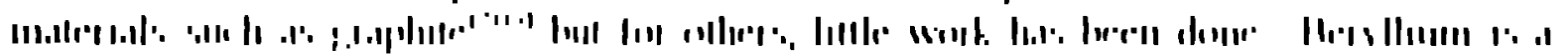

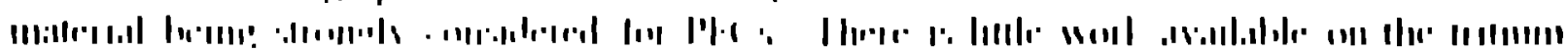

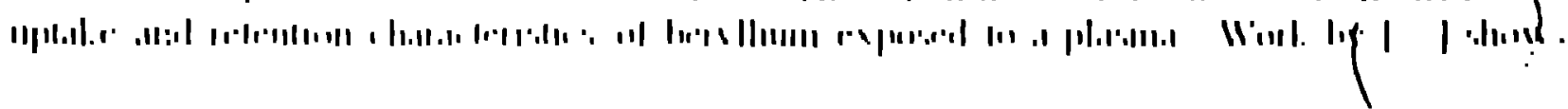


that retention as indicated by apparent solubility is strongly influenced by the composition and structure of materials, also by its manufacturing history. (1) Further evidence points to trapping that may be induced in damage caused by plasma ions and by neutrons. ${ }^{\text {(5).(6) }}$

Much of the work on PFC materials has been done on thin foils using ion beams, often of greater than prototypical ion energies. ${ }^{(7)}$ A definite lack of detailed information exists on tritium uptake properties of bulk beryllium and other plasma-facing materials. Behavior fundamentally different may be expected in the bulk than in thin foils because of the limited penetration of plasma ions.

Along with uptake and retention characteristics, the release characteristics of PI:C's need to be determined. That is, what tenperature is needed to cause the tritium to exit the miterial or structure, what is its chemical form on release, and how fast does it come oul'? What cin be done to augment or suppress release during a thermal transient? This has implications not only for accident consequence estimation, but it may impact the tritium management practices and procedures during operations.

\section{Tritium Permeation to Coolant Streams}

When tritium is injected inte the surface of a Ple(', the immediate tendency is for it Io lx' re'mitted from the surface through which it entered. Ilowever, lecenuse it is unnaltural for tritium to exist as single atoms in the gas phise at modest tempxeratures, the reemi:s:ion from the surface must be accompanied by recombination of the tritium with either other hydroggen atoms or other atonic complexes susceptible to hydropgen uptake. Thitl is usually a second onder process that reyuires the build-up of a titium concentration all the surfate.

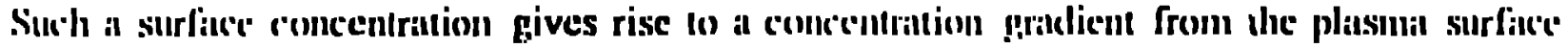

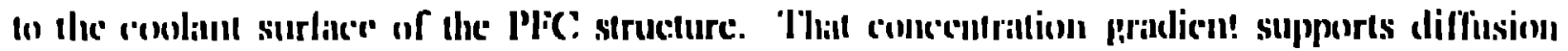

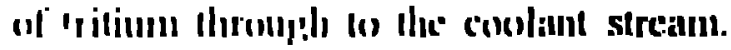

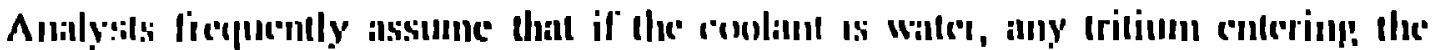

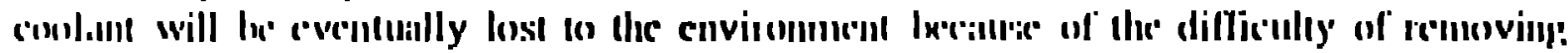

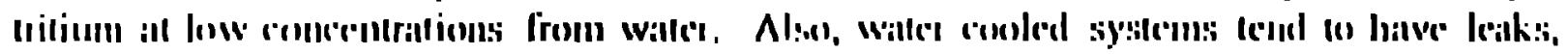

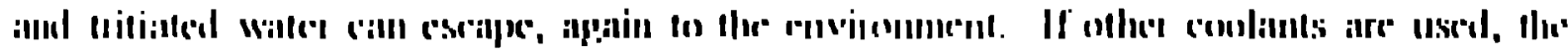

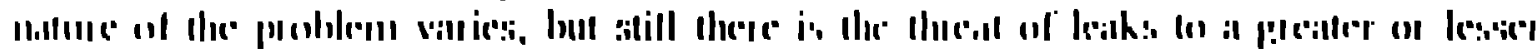

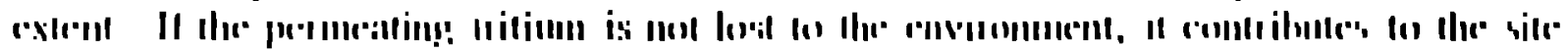

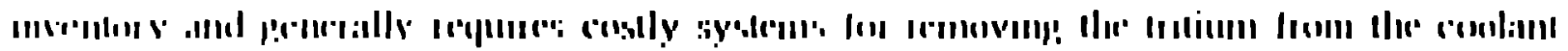

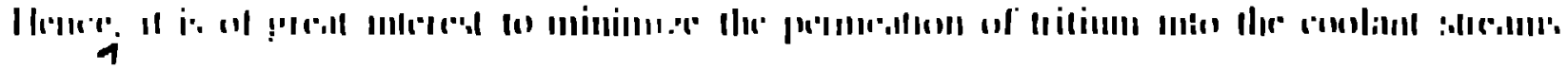

:

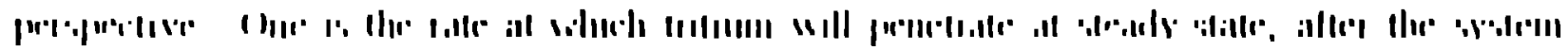

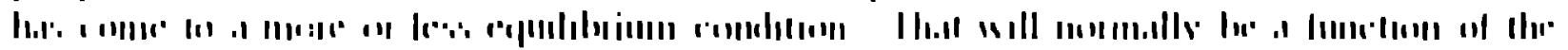
| |

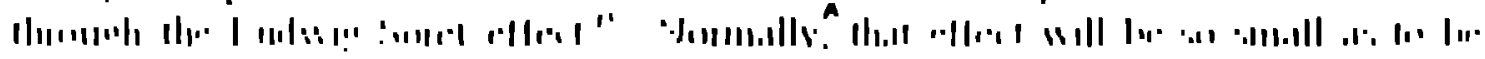
S 
pronouneed effect. Coatings maly he applied that may hinder the permeation rate. These may be relatively thick, highly recycling materials on the plasina side that will stop the inplanting ions and allow them eissy access back to the plasmia, thus preventing the baise material from secing any significant particle lond. They may also be permeation resistant coalings applied to the coolant side to restrict the now of tritium into the coolant stream.

Another aspect of tritium penneation that is of concern is the time required to get permetation breakthrough. If it is possible to retard or delay the permeration through a Plic for a time long:- rompared with the operational intervals, then it may be possible to provide a bak:e-out or other annealing process to drive the tritium from the material before it can apprecialbly permeale into a coolant stream. Such a delay may be accomplished by delilxerallely inducing traps, but it is dene all the hayard of increased inventory.

()ne prospect lor reducing txoth inventory and permeation is the crention of a highhly recyelinp! material surface. If the surface becomes porous and spoongy for a distance only moxlestly galeater than the implantation depth, then illoms or ions implanted from the plasma. whe'n they do diflus:e II a surfice, exit back in the plasmat side, greatly reducing! the fraction of implamted attoms diffusing throuph to the coolant."

\section{Release or Dispersion of Activation Products or Toxins}

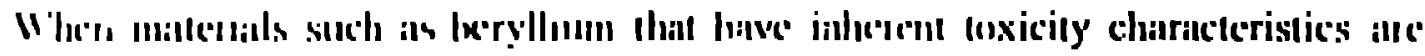

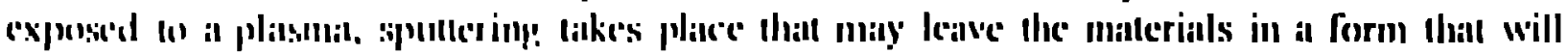

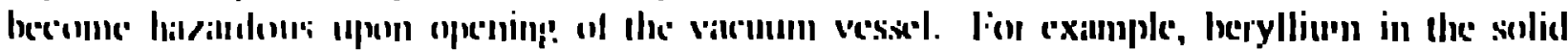

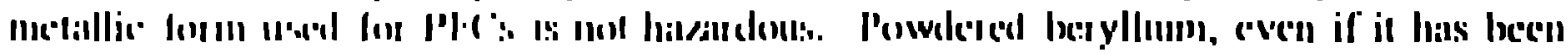

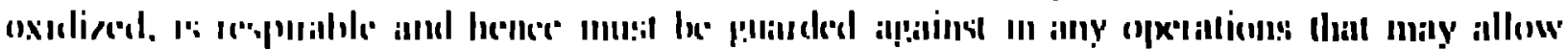

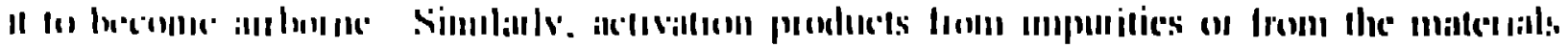

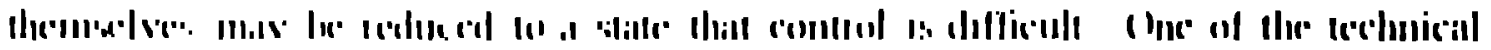

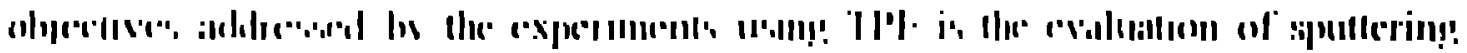

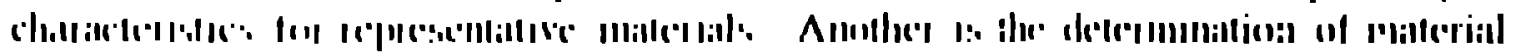

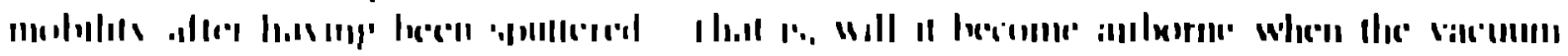

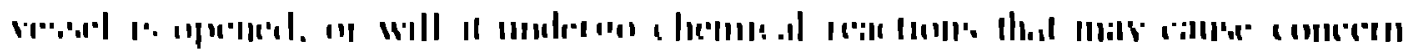

\section{OTHER ISSUES}

\section{Contribution (n) Wiste Stroams}

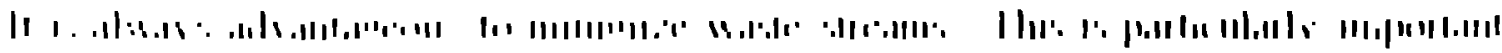

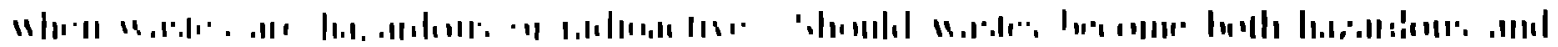

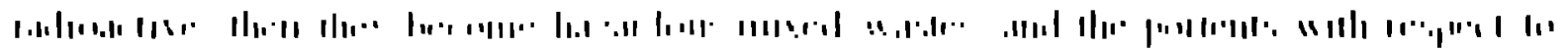
|

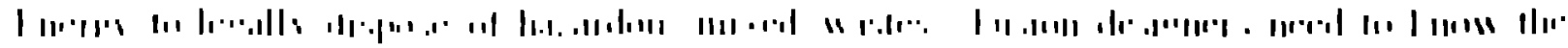

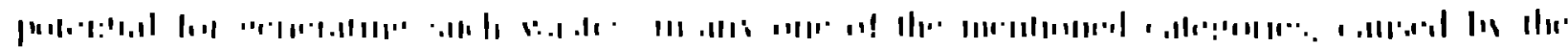


interactions of PFC.s with the plasma. The experiment should yicld information to help resolve that issue.

\section{Influences of Plasma-Facing Components on Plasma Performance}

The potential exists for matcrial from PFCs to enter the plasma, become ionized, and to detrimentally influence plasma performance. One motivation for low-Z number materials for PFCs is the need to prevent synchrotron radiation from electrons not fully stripped from ineir nurlei. Such radiation can substantially cool the plasma, reducing the encrgy confinement time. This experiment has the potential to obscrve changes in plasma emission caused by target material entering the plasma.

(ias pufting, such as now being considirec' for the lli:k divertor design, can be experimentally studied in the diense plasina thail TPl: can produce. This would provide added data for edge-physics modelers who are just lately uhle to simulnte radiation by impurity gats atoms in multi-dinensional problems. While the configuration of the Tly: plasma is markedly different from that in a divertor, measurements made on gas-plasina interactions in TPI: could be used to validnte analytical models. thus reducing uncertaintics in calculalions done for l'TI:R or other machines.

\section{TECHNICAL GOALS FOR THE EXPERIMENT}

\section{Test Configuration}

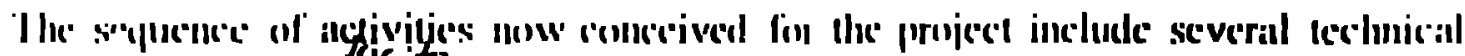
pobils, linst will he lo

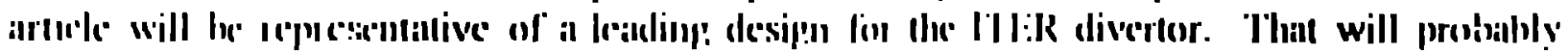

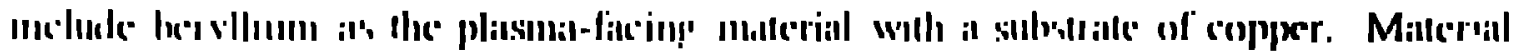

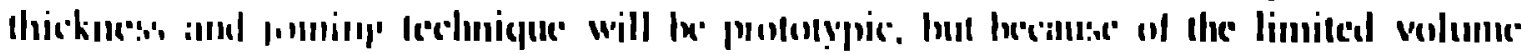

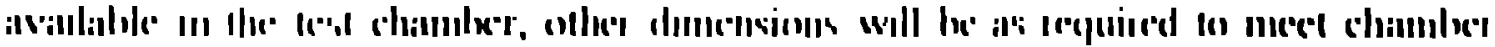
lanulitliulle.

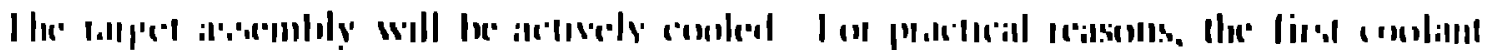

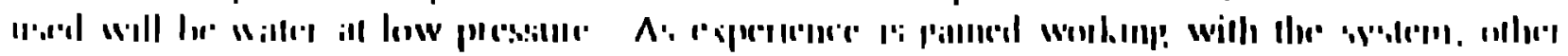

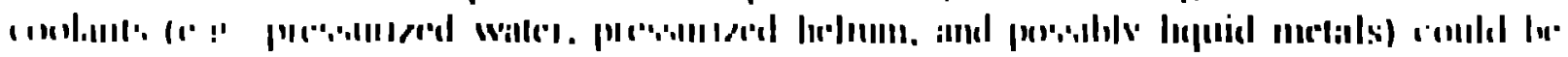

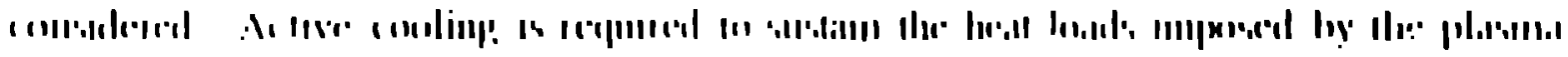

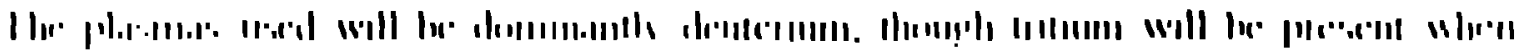

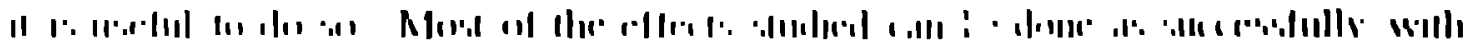

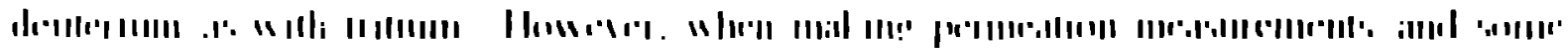
佂

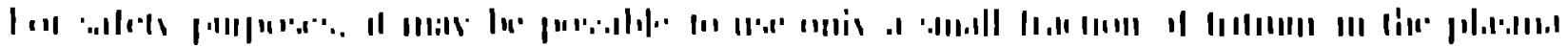

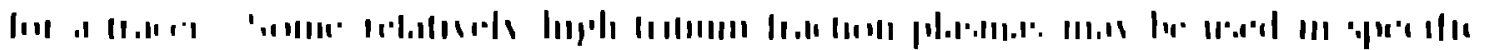


inslances. In those cases, it is probable that the full TSTA gas landling system would be used to process TPlE effluents and recover the tritiun used.

\section{Experiments}

The first experiments will evaluate permeation rates and tritium retention under nominal operating conditions. This will be done by operating the plasma column in a temporal pattern and at plasnia conditions typical of those expected for the l'II:R divertor. Permeation rates will be estimated by monitoring tritium concentrations in the coxolimt

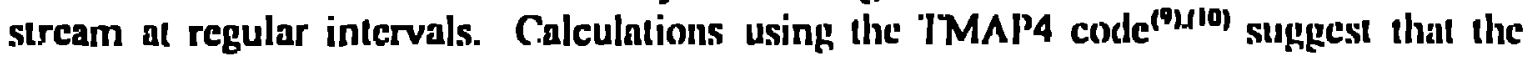
cheracteristic breaktlurough time for $2 \mathrm{~mm}$ of lecyllium on a $5-\mathrm{mm}$ thick copper substrate operuting at a heat llux of $3 \mathrm{MW} / \mathrm{m}^{2}$ with a coolant temperature of $373 \mathrm{~K}$ (beryllium surface temperalure ncar $1000 \mathrm{~K}$ ) may vary from about half an hour lo iwo montlis depending on the amount of trapping that is uperilive. Steidy statc permeation ratle throuph a $5-\mathrm{cm}$ diameter interaction areis would be iluout 1.8 ( $\mathrm{i} / \mathrm{dlay}$ if the plasma were $1 \%$ tritium.

( Ince the basic operating characteristics of the experiment are cvalualed, expetiments will he conducted to evaluate tritiun retention and relense processes for various accielent scentrios. I.0ss of flow accidents (I.()FA) or even loss of coolant accidents (I.O) $A$ ) could be simulated and the evolution of tritium to loulh to the plasma side antel to the conlant sicke

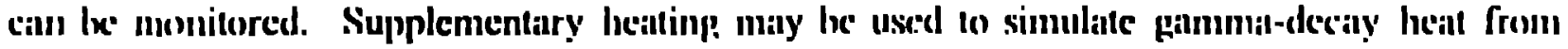

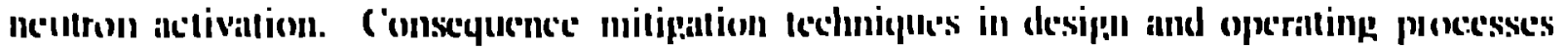
ciin lu' a'viluilled.

\section{PROGRAM}

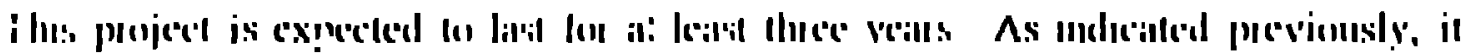

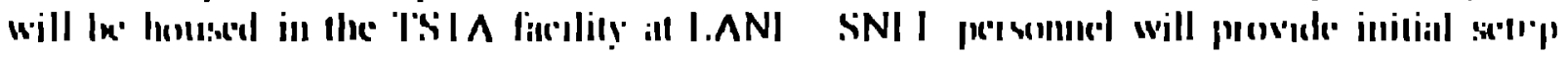

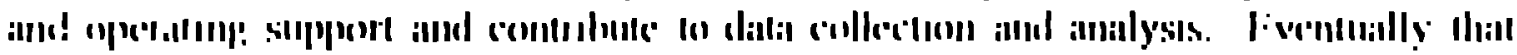

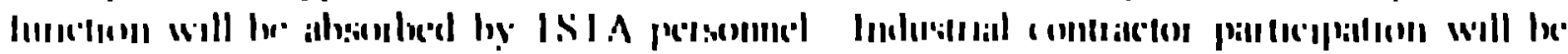
צי

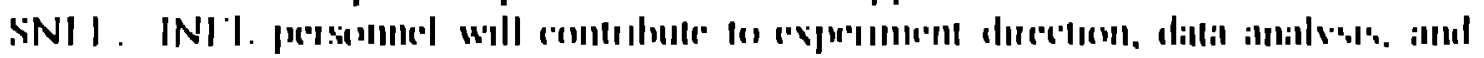

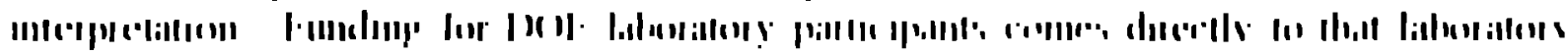

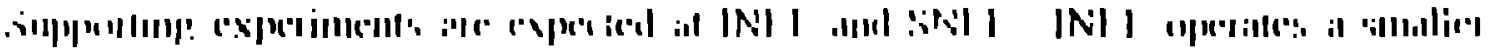

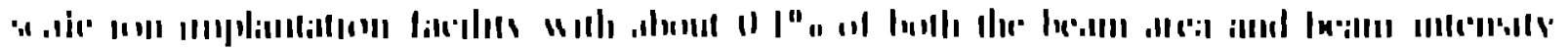

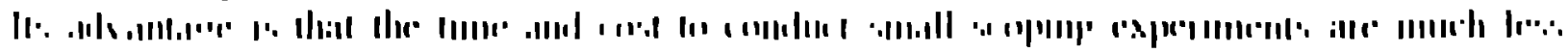
|

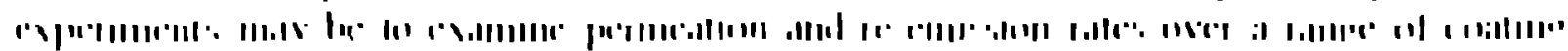

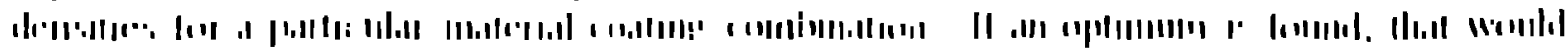
|l|r

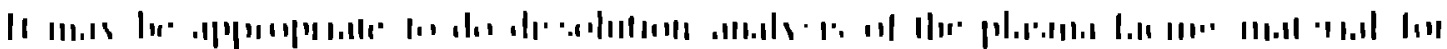

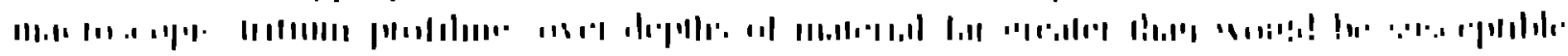


to nuclear reaction analysis or other similar techniques. SNL.l, has a strong history in analyses of this type and other related ones. That laboratory may be called on for support of this kind.

The industrial team led by MLC: Acrospace has the responsibility for detailed desipn and fabrication of the test hurdware. This design will be accomplished in consultation with the other participants in response to specific experiment requirements and current ITI:R design information. Analyses of plasma-material interactions, thermalhydraulics issues, and mechanical responses may be done by any or all of the participants. Results from appropriate analyses will be factored into the design. MDC Aerospace will be supported, in turn, by wher partners in the consortium. These include libasco Services, Inc., (ieneral Alomics, Reckwell Intcrnational, Westinghouse I:iectric, and the University of Illinois.

\section{SCHEDULE}

This: project was initiated late in 1992. It is expected fo continue at least throught 190). The general s.hedule for performing the work is:

l:xperiment : In and approvials 1993

$\begin{array}{ll}\text { lialbricille test article and start lests } & 19094\end{array}$

Re'pont on lirst lest scries 1995

liollow on experiments

Specilic milestones for techmeal accomplishments and reporting will be developed as part of the experiment plath aud the propect mannigement plant.

\section{MOTIVATION AND OUTLOOK}

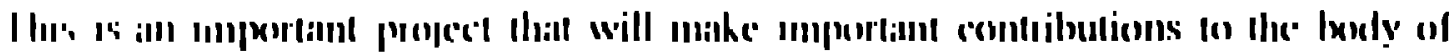

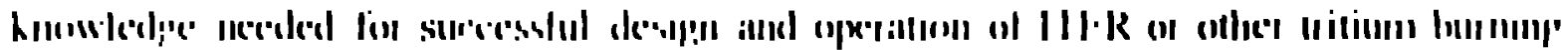

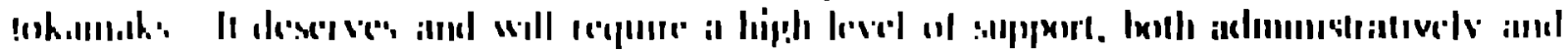

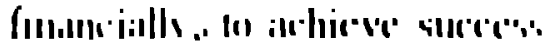

Iיוני

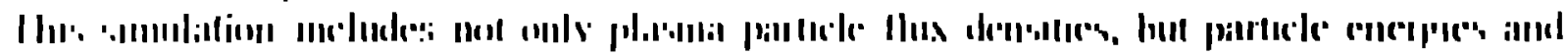

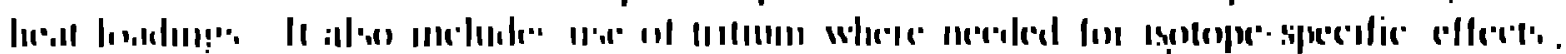

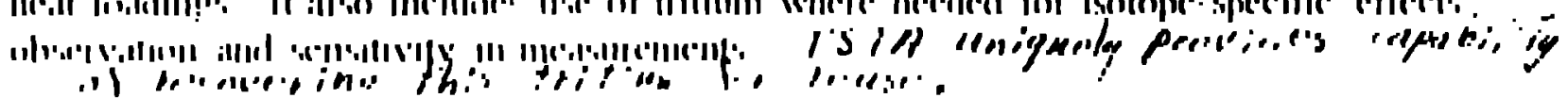

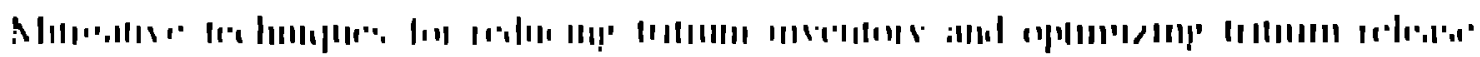

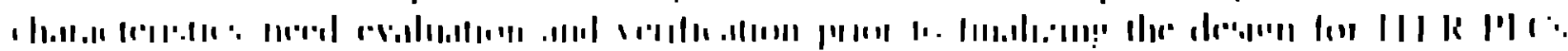

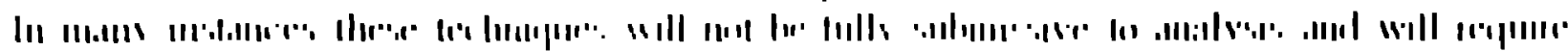

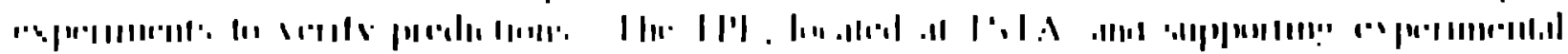

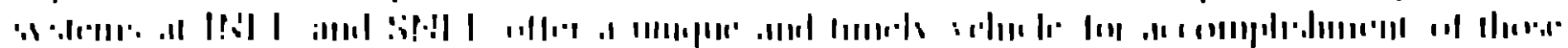

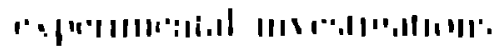


Projects like this will integrate industrial partners with DOE laboratory opcrations. It is the intent of the U.S. DOF, and indeed of ITLER, to involve private industries in the development of fusion power. This is in harmony with the need to make emerging teclunology available to private developers and specifically to involve industry in fusion to pave the way for its commercialization.

It is desirable to maintain the momentum of experience in these kinds of tests. It is time now to take the sinall-scale experimental work done by INFL, SN'Ll and other laboratories to the next level of integration and complexity. Single-effect testing needs to be joined by more integrated-efrects testir'g to verify understanding of the mechanisms involved and reveal synergisms that may exist.

\section{REFERENCES}

I. I.. Schunitz, L.. Blush, (i. C'hevilier, R. L.chmer, Y. Hirooka, P. Chia, (i. Tynan, ind R. W. Conn, "Impurity transport and retention in a gas target divertor: simulation experiments in PISC'I:S-A and modeling results," .lournal of Nuclear Malcrials 196198 (1992) $841-847$.

2. R. A. I'iuscy, W. R. Wampler, and (). J. Buzhinshij, "Tritium Relention ( 'haracteristics of Several I.ow-Z. Matterials." .Imurnal of Nuclear Maltrials 196-198 (10)2) 977-08(1.

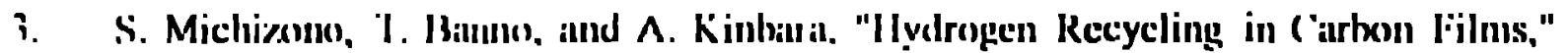

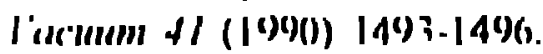

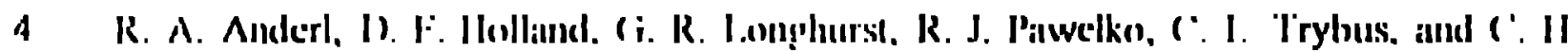

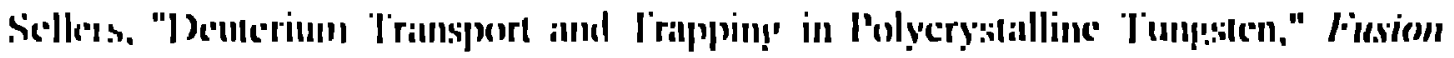

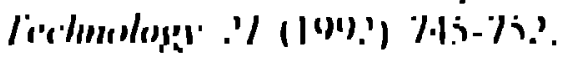

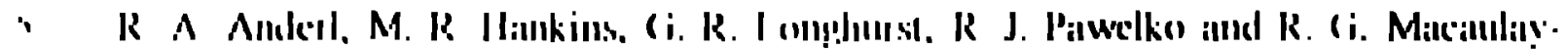

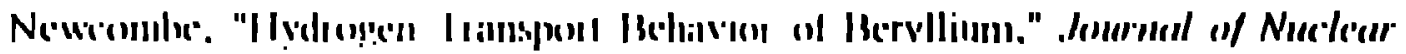

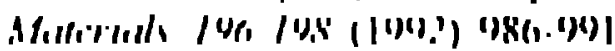

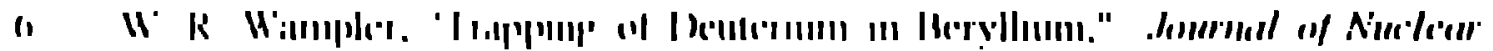
It.Mr)

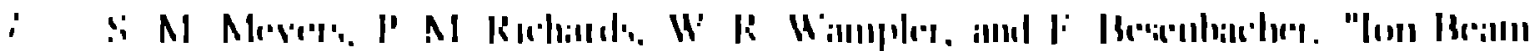
" (1)

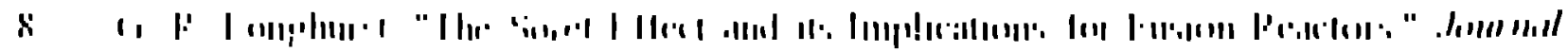

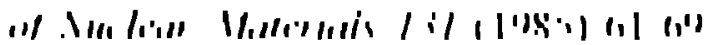

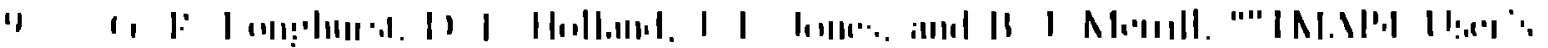


Manual," E(j(j-ISP'-10315, June 12, 1992, Idaho National Engincering Iaboratory, Idaho I'alls, Idaho, USA.

10. G. R. Longhurst, S. I. Harms, E. S. Marwil, and B. G. Miller, "Verification and Validation of TMAP4," EGG-FSP-10347, July 8, 1992, Idaho National İnginecring Laboratory, Idaho Falls, Idaho. 